two individuals. There must be a permanent centre in London for teaching and research, which would be a base for such expeditions, and for the study of the material they bring back. It is obvious that the personnel of expeditions should not be recruited in haphazard fashion from persons with few qualifications. There should be a team of specialists, engaged in teaching and research, who could be drawn upon for expedition work from time to time as occasion offered. It is sad to think that, at a time when India is much in our minds, at a time when our relations with her have reached a turning point in history, and she stands at the brink of a great experiment, there should be no professional home in London for the study and appreciation of Indian history and culture. Though there is still some doubt as to the function of a museum, those who know what the present keeper has done for the India Museum-a place where the student can now study each of its civilizations as a whole and in all its aspects-would agree that if there is to be a centre for teaching and research and a base for future expeditions, it can only be the India Museum.

A discussion followed the lecture (see p. 1029).

\section{The Future of Gaseous Fuel}

$\mathrm{T}$ 'HE town's gas industry is now well advanced into its second century of activity, although during the last half century it has, from time to time, been considered by observers as doomed to supersession sooner or later by other methods of using coal. Such opinions, based as they were on superficial knowledge, were always unwarranted, as revealed by the fact of steady growth of the use of gaseous fuel and the number of its applications. This growth has accompanied an increase in the efficiency of appliances. The present position and future of the industry have been the subject of several addresses in recent months.

Some time ago, Mr. E. V. Evans read a paper to the Royal Society of Arts on the importance of coal carbonization in the life of the nation, emphasizing the range and indispensability of its products. The modern tendency to avoid arduous and dirty tasks of domestic routine promotes the expansion of the use of gaseous fuel, which need not be stored and lends itself to automatic control. The same tendency is seen in many industrial heating operations, in spite of systems of charging which often do not encourage the free use of gas. It is only since 1920 that the sale of gas has been based on the heating value, and even now freedom to base sales on a rational system of charging is not complete. On this depends the expansion of use for large-scale operations.

Sir Harold Hartley, in his presidential address to the Society of British Gas Industries, said that the strength and vitality of an industry depends on the way it uses the resources of science. Research is the best insurance of its future, he said, and he referred to what the application of science has done to maintain and promote development of the use of gaseous fuel. The range and extent of this was given in very specific terms in a recent address of Sir David Milne Watson to the Fuel Luncheon Club, when he said that his own company-the Gas Light and Coke Co.-incurs annually an expenditure exceeding $£ 100,000$ on its research activities. In them all types of scientific skill are brought to bear on the problem of gas manufacture and purification, and utilization, including the handling of byproducts.

Mr. Evans, looking to the future, envisaged the possibility of producing gas without coke-something which a very large increase in the use of gaseous fuel might render urgently necessary. Already the industry has initiated research on the gasification of coal under pressure. The possibility of securing farreaching gasification and the production of large yields of methane and primary tars is already foreshadowed. If the early promise already shown is followed by economic success, the distribution of fuel in gaseous form will receive a great impetus. While these developments are proceeding, it will be interesting to watch the progress of the experiments made by the Soviet Union on the underground gasification of coal. Following on experiments, it is reported by the Russia Today Press Service that a commercial plant commenced operation in Gorlovka in 1937. Others are projected-one to supply Moscow-and claims are made for the cheapness of the gas.

H. J. H.

\section{University Events}

Cambridge.-C. B. Davies, of Trinity Hall, has been appointed for the present academical year to the studentship offered by Imperial Chemical Industries, Ltd.

The degree of Master of Arts has been conferred upon Dr. A. J. Bradley, assistant director of research in crystallography.

Sir Edward Mellanby, secretary of the Medical Research Council, has been appointed Rede lecturer for the year 1939 .

The following appointments in the Museum of Zoology have been made: F. T. Parrington, of Sidney Sussex College, to be director; H. B. Cott, of Selwyn College, to be curator of vertebrates, and Strickland curator; J. E. Smith, to be curator of invertebrates; Dr. G. C. Varley, of Sidney Sussex Collega, to be curator of insects. Dr. Varley has also been appointed University demonstrator in zoology.

The British Electrical and Allied Industries Research Association and the Permanent Magnet Association have offered to make jointly a grant of $£ 550$ a year to the University for the purpose of supporting research on magnetic materials under the direction of Prof. W. L. Bragg; and the Iron and Steel Industrial Research Council has offered to the University a grant at the rate of $£ 500$ a year for research on the structure of alloys, to be carried out in the Cavendish Laboratory under the same direction. In both cases, the grants will provide for the continuation of investigations which have been in progress for some time under Prof. Bragg's direction, first at the University of Manchester and afterwards at the National Physical Laboratory.

LONDON.-The title of professor emeritus of embryology in the University has been conferred on Prof. J. P. Hill, on his retirement from the University chair of embryology at University College, and that of professor emeritus of chemistry in the University on Prof. Samuel Smiles, on his retirement from the Daniell chair of chemistry at King's College. 